\title{
THE PHENOMENON OF PROSTITUTION AMONG STUDENTS
}

\author{
KAMILA WYLĘGŁY \\ Institute of Pedagogy, University of Wrocław, \\ J. Wł. Dawida 1, 50-527 Wrocław, Poland \\ E-mail address: wylegly.kamila@gmail.com \\ ORCID number: https://orcid.org/0000-0001-9787-5046
}

\begin{abstract}
Aim of research. The main goal of this paper is to analyse the phenomenon of prostitution among university students. The study presents the scale of this phenomenon and its causes.

Methodology. The study was conducted among 1,877 university students. Respondents were interviewed through an online panel survey. Students spoke about their own experience in prostitution and shared thoughts about the approval for this phenomenon.

Results and conclusions. Based on obtained answers, it was possible to identify conditioning for student prostitution, which encompasses biological, psychological, environmental, cultural, and economic factors. Moreover, students mentioned additional reasons for taking up prostitution: difficult financial situation during studies, above-average sex drive, laziness, and consumer mentality supported by the culture of promiscuity. It turned out that each of the mentioned factors may encourage students to become involved in prostitution. The analysis also drew attention to the lack of sexual education, conducive to risky sexual behaviours of young people. The research has shown that a large group of students exchange sex for money.

Originality. The risky sexual behaviours of students are still an unexplored area of knowledge. Prostitution, due to its controversial nature, is treated as a taboo subject. The article proves that the phenomenon of student prostitution is common and requires a more in-depth analysis.
\end{abstract}

Keywords: student prostitution, student sex life, risky sexual behaviours, sex education, culture of promiscuity

\section{INTRODUCTION}

Drostitution, colloquially known as the "oldest profession in the world," has 1 been controversial for many years. The term prostitution itself, as well as people undertaking it, are perceived rather negatively.

The simplest definition of prostitution is to engage in sexual intercourse for profit. In literature, however, we often find more extensive descriptions, 
enhanced by the aspect of interpersonal relationships and the diversity of clients. It can be noted, for instance, in the definition of Eugeniusz Bielicki (1992), who lists three elements constituting prostitution: frequent change of partners, financial benefits, and emotional indifference. According to K. J. Schrank ${ }^{1}$, prostitution means professional services provided by the human body (SztobrynGiercuszkiewicz, 2004). It is not a coincidence that the term "professional" was used - it emphasises the essential part of prostitution - gainful employment, which brings sexual satisfaction to the second place (Albański, 2010).

After the theoretical analysis of the phenomenon, some attention should also be paid to a person who engages in sexual activity for money. According to Wilhelm Bernsdorf (1976), it is a woman who, occasionally or professionally, gives herself to someone for business purposes (in: Lernell, 1990). The phenomenon of prostitution is most often identified with women; however, it is a misinterpretation as there is a significant number of men who undertake prostitution in order to gain material benefits or raise their social status.

In Poland, prostitution is often defined as a form of social pathology. Western countries understand it differently, often perceiving the phenomenon as an individual, professional choice. This understanding decriminalises prostitution and removes the social stigma of people practising it (Sztobryn-Giercuszkiewicz, 2004).

Nowadays, sexual sponsorship is a popular form of prostitution; it is most often defined as an arrangement consisting of meetings in exchange for gifts and material help (Glen, 2004). Renata Gardian (2010), when analysing her research results, repeatedly quoted the statements of women in sponsored arrangements. When asked about the differences between prostitution and sponsorship, they answered that the latter one is milder, although not very different from the former - it is a relationship based on receiving material benefits. However, the number of partners constitutes a significant difference. Taking sponsorship into consideration, we usually mean relatively stable agreement with one man, not sexual intercourses with multiple random customers.

As per the previous research, students are the largest group of people involved in this kind of arrangement. High costs of living during studies may be too burdensome for a family budget. Low scholarships combined with class schedules constitute unfavourable conditions for taking a full-time job and push young people into the world of broadly understood "sex-business" (Gardian, 2010).

The phenomenon of sexual sponsorship among students became so common that it gained its own name: Jacek Kurzeppa (2012) described it as universitution. It is assumed that usually women at the age of 19-22 are involved in this undertaking. These are usually well-groomed, intelligent females who often know several foreign languages - and this arouses great interest of men seeking companionship. According to the study conducted by J. Kurzeppa

1 The fragment most likely comes from the book, but the author does not provide an explanation: Schrank, J. (1886). Die prostitution in Wien in historischer, administrativer und hygienischer Beziehung, 2 Vols. Vienna: Selbstverlage des Verfassers. 
(2012), every fifth student provides sexual services for money. It is particularly popular among female students of humanities, mainly pedagogy and philology. Taking male students into consideration, student sponsorship is most common among representatives of IT, tourism and sport studies.

\section{METHODOLOGY}

Inspired by the studies of the mentioned earlier J. Kurzępa (2012), I decided to examine the intensity of the phenomenon of student prostitution and its conditioning factors. In order to answer the research question, I reached a group of 1,877 students - 1,491 women and 386 men. Large numerical discrepancy results from, among others, frequent reluctance of men to take up topics related to their own sexuality and intimate experiences. Nevertheless, it is worth noting that despite this difference, men constitute over $20 \%$ of the entire sample; it may be considered a high percentage allowing for reliable results.

Due to the controversial and embarrassing subject of the research, the interview was conducted online. It aimed at increasing the sense of anonymity of the people surveyed. The respondents were recruited using the purpose selection technique. According to the technique's premises, individuals meeting the planned criteria were selected. It was also assumed that the selection of the "sample will reflect the opinion of the entire population" (Miszczak, Walasek, 2013, p. 103).

The research was conducted between 15/10/2018-01/03/2019 among students from: Wrocław, Warszawa, Kielce, Gdańsk, Gdynia, Sopot, Łódź, Kraków, Rzeszów, Toruń, Siedlce, Lublin, Bydgoszcz, Opole, Częstochowa, and Katowice.

The study included students of the following fields: art, humanistic, legal and social, scientific and technical, medical and all others, described to in the survey as "other".

\section{Table 1.}

Percentage of participation in the research (divided into fields of study)

\begin{tabular}{lc}
\hline \multicolumn{1}{c}{ Field of study } & Percentage \\
\hline medicine & $30.8 \%$ \\
scientific and technical studies & $22.1 \%$ \\
humanities & $19.4 \%$ \\
legal and social studies & $18.3 \%$ \\
art studies & $2.9 \%$ \\
fields of study defined as "other" & $6.5 \%$ \\
\hline
\end{tabular}

Source: author's research.

It can be seen that the largest group of participants constitutes medical students (580 people) as they were most willing to complete the questionnaire; it may indicate their interest in the subject of prostitution (it is also worth adding that they often sent private messages with information that the research topic 
is interesting). The second group includes students of scientific and technical studies (416 people). The students of the humanities (365 people), as well as legal and social studies (345 people), represent a slightly smaller percentage. The students of the fields identified in the study as "others" formed a group of 117 people. The smallest group of students turned out to study art (54 people).

The study was carried out using a questionnaire. The research tool consisted of 51 questions. Most of them met the criteria of a four-degree estimate scale - the respondent could refer to a given statement choosing one from the following options: strongly agree, agree, disagree, strongly disagree. The questionnaire also included two open questions: What do you think about prostitution as a form of earning money while studying? and How would you describe your attitude towards students who turned to prostitution? Why?

The use of both qualitative and quantitative methods (methodological triangulation) in research was aimed at a deeper analysis of the problem and a better understanding of the phenomenon under study.

\section{TEST RESULTS}

Analysing the obtained results, it was necessary to divide them into the ones concerning prostitution (simple, instrumental "sex for money," excluding the aspect of interpersonal bonds) and sexual sponsorship (more complex relationship between the sponsor and the supported woman). It turned out that many students do not treat both phenomena in the same way and claim that these terms should not be used interchangeably. To confirm that, examples of responses from the surveys:

- "I do not consider sponsorship to be a form of prostitution" (female, 23, medical studies);

- "First of all, prostitution is not the same thing as sponsorship" (female, 18, scientific and/or technical studies);

- "In my opinion, sponsorship and prostitution are not the same (...). Prostitution is just like a profession. Sponsorship is more like a form of seasonal work, or a one-time thing, in order to improve the financial situation" (male, 22, medical studies).

The results of the conducted research prove that a significant part of students engages (or engaged in the past) in prostitution. The figures are presented in Table 2.

\section{Table 2.}

Percentage of students engaged in prostitution

\begin{tabular}{lc}
\hline Percentage of people who have had sex for money & $17.2 \%$ (321 people) \\
\hline $\begin{array}{l}\text { Percentage of people who remain/took part in } \\
\text { sponsored arrangements }\end{array}$ & $10.4 \%$ (195 people) \\
\hline
\end{tabular}

Source: author's research. 
The above values show that the phenomenon of prostitution among students is common. It is also quite interesting that sponsorship agreements are less frequently practised - after all, society assesses them morally higher than prostitution, understood in a colloquial way.

After analysing the data showing the participation of students in the procedure, it is necessary to consider what motivates young people to turn to prostitution. Based on the conducted research, we can distinguish three basic groups of factors conditioning student engagement in prostitution:

1. Biological and psychological factors.

A strong relationship between gender and prostitution was noticed - women were involved more often. It may be caused by the fact that men are usually interested in making use of such services. Studies have also shown the relationship between prostitution and the rebellious period of adolescence as well as between the lack of responsibility for oneself and one's decisions.

2. Environmental and cultural factors.

I included the rebellious period of adolescence in this group of factors as well - it was difficult to unequivocally state, based on the results, how much "troubles" during the period of puberty are conditioned by hormonal changes and personality, and how much by the influence of the environment and peer groups. As demonstrated in the group of biological and psychological factors, prostitution may be conditioned by the rebellious period of adolescence.

The place of origin also turned out to be an important factor. Research shows that people who tend to have sex for money most often come from rural areas. What is important, student prostitution is the most popular in metropolitan areas whereas in smaller student towns the level of approval for the phenomenon is rapidly decreasing. Due to this fact, prostitution may be particularly common among people who come from the countryside and move to big cities for the duration time of their studies. This is obviously associated with an increased sense of anonymity and reduced social control.

The influence of religiousness was also taken into account; it turned out to correlate negatively with the tendency to undertake prostitution. In order to analyse the environmental and cultural factors, I decided that it would also be significant to check the influence caused by the field of study on the willingness to turn to prostitution. I assumed that staying in a specific environment is inextricably linked to the internalisation of general axionormative systems, which may be associated with an increased level of approval for exchanging sex for money. It turned out, however, that the relationship between these factors cannot be indicated because the result is statistically insignificant.

3. Economic factors.

Research shows a strong relationship between student prostitution and a difficult financial situation at home. It appears that people prone to pro- 
stitution grew up in poor families, where the parents were unable to cope with all the material needs of their children.

Apart from the above, students mentioned four additional reasons:

- difficult financial situation during studies, as indicated by a student (female, 23) of art studies: "Sometimes there is no choice; parents have money, but they prefer to invest in siblings; I get 50 PLN per week, of which I spend 30 PLN on getting to Torun on Monday and returning on Friday. Asking for additional funds, I always get a refusal; it is hard for me to find a regular job because I have to attend classes at different times of the day";

- above-average sex drive - says a 21-year-old woman of the scientific degree: "I have problems with my sexuality. I organised meetings with sponsors not because of lack of money, but because of abnormally high sexual needs";

- consumer mentality supported by the culture of promiscuity - can be proved by the statement of a law student (female, 19): “(...) I think that it [prostitution] is not always caused by the lack of sufficient funds, sex is a nice thing, so why not to take advantage of it?";

- laziness, unwillingness to undertake a "normal/regular" job - "People choosing this immoral path are too lazy to look for a decent job. They want to get much money quickly, and life is not really about that" (female, 19); "I think that only inept or lazy people do it. They are looking for a quick and easy way to make money while they could work for less but preserve their dignity" (female, 19).

The extremely important factor conditioning prostitution is the lack of sex education or its insufficient level in Poland. Lack of proper preparation in family life education can push young people into the area of risky sexual behaviours; these are actions and behaviours considered to have a potentially harmful effect on one's health. They include: too early age of sexual initiation, non-usage of contraception, multiplicity of sexual partners, casual sexual contacts, all forms of sexual violence, and eventually prostitution and sponsoring. People undertaking risky sexual behaviours are exposed to an increased risk of sexually transmitted diseases and unwanted parenthood (Imacka, \& Bulska, 2012).

The most important period of building awareness and sexual identity is the period of adolescence. However, Zbigniew Lew-Starowicz and Alicja Długołecka (2006) emphasise that introducing a young person into the world of their own sexuality should take place much earlier. Postponing this moment of introduction to adolescence is not only late but also risky. The authors also emphasise that increasing sexual awareness is a responsibility instilled not only by school but also by parents; nonetheless, the cultural shaping of the mentality of many Poles makes it impossible to openly talk about sexuality at home. It results in the creation of communication barriers which are extremely difficult to overcome.

Sexual awareness of children and youth at the school level is also an issue. Sex education in Polish schools is regulated by the Act of January 7, 1993, and 
the Regulation of the Minister of Education of August 12, 1999, with amendments from 2002, 2009, 2012, and 2014. According to them, the basic goals of sexual education classes at school should be: to show a holistic approach to human anatomy and sexuality, and to shape appropriate pro-health and pro-family attitudes.

The optional form of family life education is one of the greatest weaknesses of the Polish education system. Currently, based on the Ordinance of the Minister of Education from August 10, 2009, parents, legal guardians, or students of age have a possibility to resign from/sign their child out of participation in classes. Thus, it can be assumed that from the point of view of the Ministry of Education, subjects concerning human sexuality do not constitute a priority in the core curriculum content (Gojarska et. al., 2018).

Analysing the content of sex education classes in accordance with the new core curriculum for grades IV-VIII, it can be noted that emotional, psychological, social, and biological aspects of human sexuality were included. However, the new core curriculum does not contain a list of mandatory topics to be introduced by teachers. This may result in the omission of selected subjects, depending on the personal preference of a particular teacher (Gojarska et. al., 2018).

\section{CONCLUSIONS}

The study has shown that the phenomenon of prostitution among Polish students is quite common. It appears particularly often among students in big cities (e.g. Wrocław, Kraków), which is inseparably connected with the increased sense of anonymity. It is worth adding that the phenomenon of sexual sponsorship is spreading not only in Poland. Swansea University research indicates that 1 in every 20 students in the UK provides sexual services for money (mostly male students). Young people are also involved in cybersex and pornography industry on the Internet. Asked about the motives behind this decision, British students point to a difficult financial situation, but also curiosity and pleasure derived from sex (TheGuardian.com, 2015).

Research conducted in Nigeria also confirms the problem of student prostitution (Ikechukwu-Ilomuanya, Onyechi, Iwuagwu, 2018). This phenomenon is spreading among students of both state and federal universities. The growing prevalence of prostitution in an academic environment increases the public health risk indicator. What is more, the student involvement in the sex industry has a negative impact on their academic performance (Oyeoku, Ngwoke, Eskay, Obikwelu, 2014).

The high level of approval for the phenomenon of student prostitution may be disturbing. These may be proved by the following statements:

- "I do not mind it because we are only humans, and everyone is an architect of their fate. We make decisions we consider the most appropriate at the moment" (male, 23); 
- "A way like many others. I think such choice is even better and morally higher than work that involves cheating other people (e.g. call centres, tricking someone into buying something, tricking older people into signing unfavourable agreements)" (female, 27);

- "I am very liberal, I do not care about who and why sleeps with someone else. Rector's scholarship at some universities is ridiculously low. In modern times working hard does not pay off, so I am not surprised by the phenomenon of prostitution or earning on sex webcams. After all, everyone wants to have enough money for their pleasures" (female, 22);

- "If there is someone who would like to pay me some money, I would gladly do anything they want. I have never met anyone like this [a prostitute] in my life, but I think it is good for them that they find people paying them for an hour of pleasant work" (male, 23);

In some of the obtained responses, one can note the demanding attitude the respondents clearly emphasise that social support at universities is too low, and, therefore, the phenomenon of student prostitution is caused by the university policy. What is more, naming prostitution a "pleasant" form of earning can be a sign of moral degradation and the fall of higher values.

The conducted research proves that the prostitution of students is conditioned by three groups of factors - biological and psychological, environmental and cultural, and economic. Each of the mentioned factors, to a lesser or greater extent, persuades students to turn to prostitution. It is also necessary to indicate the institutional factor, namely the lack of sex education at school or insufficient level of information shared in sex education classes. In the Polish education system, family life education classes are often organised unsystematically, selectively and by people who do not have the proper preparation.

The phenomenon of prostitution among students is slowly expanding to a global scale. It is a problem not only in Poland but also around the world. This is undoubtedly an area for further considerations for educators, psychologists, and sociologists.

\section{REFERENCES}

1. Albański, L. (2010). Wybrane zagadnienia z patologii spotecznej [Selected issues from social pathology]. Jelenia Góra: Kolegium Karkonoskie w Jeleniej.

2. Bielicki, E. (1992). Zjawiskowe formy patologii spotecznej w Polsce w percepcji ocenie uczniów szkót średnich [Phenomenological forms of social pathology in Poland in the perception of high school students]. Bydgoszcz: WSP.

3. Bernsdorf, W. (1976). Socjologia prostytucji [The sociology of the prostitution]. In: H. Giese (Ed..), Seksuologia [Sexology], trans. H. Flatau. Warszawa: PZWL.

4. Gardian, R. (2010). Zjawisko sponoringu jako forma prostytucji kobiecej [The phenomenon of sponsoring as a form of female prostitution]. Kraków: Impuls.

5. Glen, M. (2004). Studentka szuka sponsora... [The student is looking for a sponsor...]. Eurostudent, vol. 96, 12. doi: 10.2307/40157195

6. Gojarska, M., Kuik, M., Laube, L., Liszewska U., Madej, O. (2018). Edukacja seksualna w Polsce $\mathrm{w}$ kontekście promocji zdrowia seksualnego vs tabu seksualne [Sexual education in Poland in the context of sexual health promotion vs sexual taboos]. Psychoseksuologia, vol. 4, 110-120. 
7. Ikechukwu-Ilomuanya, A. B., Onyechi, K. C. N., Iwuagwu, L. C. (2018). Youth advertising as prostitution among female undergraduates of tertiary institutions in Nigeria. Journal of Educational Foundations (JEF), Vol. 7, Issue 1, 10-17.

8. Imacka, J., Bulsa, M. (2012). Ryzykowne zachowania seksualne młodzieży jako czynnik zwiększający ryzyko zakażenia chorobami przenoszonymi drogą płciową [Risky sexual behavior of adolescents as a factor increasing the risk of infection with STDs]. Hygeia Public Health, vol. 47(3), 272-276.

9. Kurzępa, J. (2012). Młodzi, piękne i niedrodzy... Młodość w objęciach seksbiznesu [Young, beautiful and unproductive... Youth in the embrace of the sex business]. Kraków: Rubikon.

10. Lernell, L. (1990). Zarys kryminologii ogólnej [Outline of general criminology]. In: K. Imieliński (Ed.), Seksuologia kulturowa [Cultural sexology]. Warszawa: PWN.

11. Lew-Starowicz, Z., Długołęcka, A. (2006). Edukacja seksualna [Sex education]. Warszawa: Świat Książki.

12. Miszczak, A., Walasek J. (2013). Techniki wyboru próby badawczej [Techniques for selecting a research sample]. Obronność - Zeszyty Naukowe Wydziału Zarządzania i Dowodzenia Akademii Obrony Narodowej, vol. 2(6), 100-108.

13. Oyeoku, E. K, Ngwoke, D. U, Eskay, M., Obikwelu, C. L. (2014). Perceived Impact of Prostitution Tendencies on Academic Performance of University Undergraduates in South East, Nigeria. Education. Volume 3, Issue 1, 45-47.

14. Schrank, J. (1886). Die prostitution in Wien in historischer, administrativer und hygienischer Beziehung, 2 Vols. Vienna: Selbstverlage des Verfassers

15. Sztobryn-Giercuszkiewicz, J. (2004). Psychologiczne aspekty prostytucji [Psychological aspects of prostitution]. Łódź: DAJAS.

16. TheGuardian.com. (2015). Students turn to sex work to make ends meet at university, study finds. Retrieved from: https://www.theguardian.com/education/2015/mar/27/ university-students-sex-work-living-costs-tuition-fee-debts 